\title{
Dampak Covid-19 Terhadap Indeks Harga Saham IDX BUMN20 Pada Tahun 2020
}

\author{
${ }^{1}$ Agus Munandar, ${ }^{2}$ Aulia Safira, ${ }^{3}$ Edwin Wiguna \\ ${ }^{1}$ Univesitas Esa Unggul, ${ }^{2,3}$ Universitas Islam Indonesia \\ Agus.munandar@esaunggul.ac.id
}

\begin{abstract}
This article analyzes the impact of stock price efficiency on the Covid-19 event in 2020. As a capital market tool, shares are interpreted as evidence that a person has equity participation in a company or limited liability company. The emergence of the impact of Covid-19 on the price index is detrimental to the country's economy. StateOwned Enterprises (BUMN), which are the drivers of economic growth, has also been affected by the Covid-19 pandemic. This analysis needs to be carried out to find out the impact of Covid-19 on the stock price of IDX BUMN20 regarding the effects before and before the outbreak of the Covid-19 virus in Indonesia in 2020. The research method used is exploratory descriptive with a quantitative approach and the data collected is descriptive. Secondary data from the IDX and the Central Statistics Agency regarding the condition of economic growth and the SOE stock price index in 2020. Based on the results obtained, the first conclusion is that Indonesia's economic growth from 2019 was $5.02 \%$ and in 2020 was 2.07\%, so that economic growth decreased from 2019 to 2020 by 2.95. Furthermore, the IDX BUMN20 stock index also fell to $18.39 \%$ throughout 2020.

Keywords: Covid-19, stock market, IDX BUMN20, economic growth, descriptive exploratory
\end{abstract}

\begin{abstract}
ABSTRAK
Artikel ini menganalisis dampak efisiensi harga saham pada peristiwa Covid-19 tahun 2020. Sebagai alat pasar modal, saham dimaknai sebagai bukti bahwa seseorang memiliki penyertaan modal pada suatu perseroan atau perseroan terbatas. Munculnya dampak Covid-19 terhadap indeks harga saham merugikan perekonomian negara. Badan Usaha Milik Negara (BUMN) yang menjadi penggerak pertumbuhan ekonomi juga terkena imbas dari pandemi Covid-19. Analisis ini perlu dilakukan untuk mengetahui akibat dari Covid-19 terhadap harga saham IDX BUMN20 tentang bagaimana dampak sebelum dan sesudah mewabahnya virus Covid-19 di Indonesia tahun 2020. Metode penelitian yang digunakan yaitu deskriptif eksploratif dengan pendekatan kuantitatif dan data yang dikumpulkan bersifat deskriptif. Data sekunder dari BEI dan Badan Pusat Statistik mengenai kondisi pertumbuhan ekonomi dan indeks harga saham BUMN tahun 2020. Berdasarkan hasil yang diperoleh, kesimpulan pertama adalah pertumbuhan ekonomi Indonesia dari tahun 2019 sebesar 5,02\% dan pada tahun 2020 sebesar 2,07\%, sehingga pertumbuhan ekonomi menurun dari tahun 2019 ke 2020 sebesar 2,95. Selanjutnya, indeks saham IDX BUMN20 juga turun menjadi 18,39\% sepanjang tahun 2020.
\end{abstract}

Kata kunci: Covid-19, saham, IDX BUMN20, perekonomian, eksploratif deskriptif

\section{PENDAHULUAN}

Pada akhir tahun 2019 telah terjadinya penyebaran virus Covid-19 yang pertama kali mencuat di Wuhan. Wabah pandemi virus corona yang dimulai pada akhir 2019 ini telah membuat ancaman terhadap sektor kesehatan dan kini 
berdampak signifikan terhadap sektor perekonomian negara. Dampak sebelum pandemi yang dialami sangat berbeda dengan saat ini. Sebelum pandemi, perekonomian negara relatif stabil dibandingkan setelah pandemi Covid-19 yang awalnya tidak berdampak pada pasar saham, namun seiring bertambahnya jumlah korban yang dikonfirmasi, pasar saham bereaksi negatif. Berdasarkan laman Data Sebaran Covid-19 pada tahun 2020 lebih dari 30.514 kasus infeksi Covid-19 yang dilaporkan. Indonesia juga memiliki kasus virus corona terbanyak kedua di ASEAN (CNN Indonesia). Sementara itu jumlah kasus secara global kini mencapai lebih dari 6,7 juta dan jumlah kematian melewati angka 395.000 pada (07/06). Hal ini juga mengakibatkan penurunan harga pasar saham, terutama sesudah WHO menyatakan bahwa pandemi Covid 19 mengakibatkan anomali return negative (Liuet al., 2020).

Pergerakan pasar saham yang dipengaruhi oleh Covid-19 mengakibatkan peningkatan inefisiensi di pasar saham serta penurunan bursa saham di seluruh dunia (lalwani and Meshram, 2020). Hal tersebut dapat berpengaruh terhadap investor dalam membuat keputusan dan memberikan pengaruh buruk pada pasar saham, dimana masyarakat akan lebih berhati-hati dalam berinvestasi karena proyeksi pasar saham sedang terganggu dengan adanya Covid-19. Investor akan memilih untuk berhenti berinvestasi karena ketidakjelasan supply chain (Pepinsky \& Wihardja, 2011). Pandemi Covid-19 memberikan pengaruh bagi perekonomian di Indonesia terutama pada sektor pasar saham yang menjadi salah satu jenis surat berharga yang dipasarkan pada bursa. Saham dapat memberikan laba yang menarik sehingga banyak diminati oleh para investor sebagai alat berinvestasi. Saham dapat diartikan sebagai indikasi penyertaan modal pada perusahaan atau perseroan terbatas. Setelah memberikan modal, maka pendapatan perusahaan dan aset perusahaan dapat diklaim oleh pihak pemberi modal. Setiap orang yang mempunyai saham berarti mereka memiliki penyertaan modal atau sebagai orang yang mempunyai perusahaan yang mengeluarkan saham tersebut. Pembeli saham membayar perusahaan dari bursa efek, lalu mendapat sertifikat saham yang menjadi bukti kepemilikan saham dan kepemilikan tersebut dicatat pada daftar saham perusahaan.

Perusahaan menjadikan pasar saham sebagai sumber penanaman modal yang penting. Pemasaran kepemilikan perusahaan pada pasar modal dapat meningkatkan anggaran bagi perusahaan yang sudah go public. Biaya tersebut dapat digunakan untuk meningkatkan kinerja perusahaan dan menjadi sumber modal jangka panjang. Selanjutnya hal penting yang harus dilakukan perusahaan adalah dengan menjaga kepercayaan para investor, karena hal ini juga telah dilaksanakan oleh beberapa penelitian yang bertautan dengan pasar saham (Bose and Mukherjee, 2005). Pertumbuhan ekonomi juga dipengaruhi oleh perkembangan pasar saham (Sulistyowati and Rahmawati, 2020). Pertumbuhan ekonomi memiliki hubungan positif dengan efisiensi pasar saham baik itu dalam kurun waktu yang pendek maupun kurun waktu yang panjang, hal tersebut merupakan hasil dari penelitian sebelumnya (Masoud, 2013).

Badan Usaha Milik Negara (BUMN) juga terimbas dengan kondisi saat ini. Padahal BUMN memiliki peran penting sebagai pendorong bagi pertumbuhan ekonomi agar dapat kembali berputar. Berdiri sejak tahun 1973, BUMN bertanggung jawab dalam melakukan pemeliharaan bagi perusahaan negara atau Badan Usaha 
Milik Negara. Sebelum mengalami perubahan dan perkembangan, organisasi BUMN menjadi bagian Departemen Keuangan Republik Indonesia. IDX BUMN20 yang mengukur kinerja harga saham dari 20 perusahaan milik negara ini juga tertekan akibat adanya pengaruh Covid-19, dimana harga saham juga mengalami penurunan seiring turunnya pertumbuhan ekonomi. Covid-19 memberikan pengaruh terhadap berbagai sektor yang ada pada IDX BUMN20 yang membuat berbagai sektor mengalami penurunan kinerja yang signifikan.

Pentingnya menganalisis pengaruh dampak dari virus pandemi corona terhadap sektor pasar saham dan perekonomian menjadi tolak ukur beberapa perusahaan dan pemerintah untuk mengatur aliran dana asing guna menstabilkan angka indeks dan nilai ekonomi. Kajian ini juga dilakukan untuk melihat seberapa kuat influencer Covid19 terhadap indeks saham IDX BUMN20. Oleh sebab itu, penelitian ini akan melakukan analisis data untuk melihat bagaimana pergerakan harga saham IDX BUMN20 Indonesia selama pandemi Covid-19 pada tahun 2020.

\section{LANDASAN TEORI}

Covid - 19

Wuhan merupakan kota yang pertama kali terdampak virus Covid-19 di akhir tahun 2019. Virus ini menjalar dengan cepat ke berbagai negara termasuk Indonesia. Sejak masuknya virus tersebut di Indonesia, tepat pada 2 Maret tahun 2020, pemerintah indonesia menyatakan terdapat dua kasus pasien Indonesia yang terinfeksi Covid-19. Covid-19 bermula dari SARS-CoV-2 yang merupakan variasi baru dari Coronavirus. Virus ini mengakibatkan terjadinya peradangan pada saluran pernapasan seperti flu serta infeksi paru-paru. Di akhir tahun 2020 beberapa informasi kasus menyatakan bahwa virus Covid-19 berkembang menjadi berbagai macam varian baru.

Awal mulanya gejala ini cukup susah untuk dilihat. Hal ini karena tidak semua orang yang terjangkit menunjukkan gejala awal dari virus tersebut. Perlu waktu 2 hingga 14 hari untuk mengetahui orang yang terjangkit virus Covid-19 memastikan gejalanya. Salah satu cara untuk mencegah infeksi virus Covid-19 yakni dengan menjaga kebersihan dan kesehatan. WHO memberitahukan bahwa cara awal untuk menghindari infeksi virus corona adalah dengan selalu mencuci tangan, menutup mulut dan hidung ketika batuk atau flu, serta mengkonsumsi makanan yang matang dan tinggi vitamin. Selain itu menghindari kontak langsung dengan orang lain terutama dengan orang yang terjangkit virus karena dapat mencegah terjadinya penularan (CCN Indonesia).

\section{Pasar Saham}

Saham merupakan produk pasar keuangan yang populer. Pasar saham adalah media yang menyediakan transaksi perdagangan saham. Ada dua jenis saham di Indonesia, yakni saham biasa dan saham preferen. Saham biasa merupakan pemilik saham yang sebenarnya sedangkan saham preferen merupakan saham yang memberi sepenuhnya hak kepada pemiliknya agar mendapat pembayaran dividen yang lebih besar. Dana yang didapatkan bisa meningkatkan kinerja serta menjadi sumber pendanaan jangka panjang. Pasar saham memiliki hubungan yang cukup erat dengan pertumbuhan ekonomi, dimana pasar saham dipengaruhi dari kondisi perekonomian suatu negara. 
Pasar saham juga menggambarkan bagaimana kondisi ekonomi pada suatu negara. Banyak perusahaan yang bergabung ke bursa dengan tujuan ekspansi. Pasar saham menjadi salah satu bagian penting dari ekonomi free-market yang bergantung pada penwaran dan permintaan. Pasar saham juga dapat memberikan fasilitas yang aman serta mempunyai regulasi. Dengan pasar saham para investor dapat berinteraksi dengan aman serta risiko operasi yang minim. Selain itu perusahaan juga akan mendapat keuntungan dari keberhasilan dari pertumbuhan perusahaan melalui capital gain serta dividen.

\section{IDX BUMN20}

Perdagangan dan penawaran efek diselenggarakan oleh Bursa Efek Indonesia (BEI). pada tanggal 1 Desember $2007 \mathrm{BEI}$ mulai dioperasikan oleh pemerintah. BEl adalah penggabungan antara dua bursa efek yaitu jakarta dan surabaya. Keduanya digabungkan dengan tujuan untuk efektivitas transaksi dan operasional. Bursa Efek Surabaya menjadi obligasi sedangkan Bursa Efek Jakarta menjadi pasar saham. Transaksi untuk kepentingan nasabah maupun pribadi yang terjadi di Bursa merupakan tanggung jawab anggota BEI. Terjadi 3 kali perubahan sistem yang diterapkan oleh BEI. Awalnya BEI menerapkan sistem manual. Selanjutnya pada tanggal 22 Mei 1995, BEI mengganti sistem manual menjadi sistem perdagangan yang bernama Jakarta Automated Trading System (JATS). Lalu pada tanggal 2 maret 2009 terjadi perubahan kembali menjadi JATS-NextG.

Suatu informasi yang berkaitan dengan kinerja suatu pasar saham dijelaskan di dalam suatu indeks yang disebut dengan indeks pasar saham. Dimana pergerakan harga saham akan digambarkan melalui suatu indeks. Badan Usaha Milik Negara (BUMN) dan Badan Usaha Milik Daerah (BUMD) adalah badan yang diukur oleh indeks saham IDX BUMN20. Indeks BUMN20 mengukur 20 kinerja saham perusahaan. Negara merupakan pemegang modal terbesar pada Badan Usaha Milik Negara (BUMN) serta BUMN berperan penting dalam perekonomian Indonesia.

\section{METODOLOGI}

Penelitian ini dilaksanakan dengan metode analisis eksploratif deksriptif dengan pendekatan kuantitatif. Penelitian eksploratif deskriptif bertujuan dalam menggambarkan suatu fenomena, dimana dalam penelitian ini tidak hanya menggambarkan suatu variabel, gejala atau keadaan. Pengamatan dilakukan dengan menganalisis indeks saham IDX BUMN20 Indonesia dan pertumbuhan ekonomi pada tahun 2020. Analisis deskriptif dilakukan berdasarkan data dari IDX 2020 dan Badan Pusat Statistik. Data sekunder dari IDX adalah data indeks saham BUMN Tahun 2019 hingga 2020 serta data pertumbuhan ekonomi pada tahun 2020.

\section{HASIL DAN PEMBAHASAN}

Berdasarkan grafik 1 menunjukkan bahwa pertumbuhan ekonomi sebelum adanya Covid-19 tergolong stabil, akan tetapi terjadi penurunan yang cukup drastis pada tahun 2020, dimana tahun tersebut merupakan awal mula masuknya Covid-19 
di Indonesia. Perekonomian Indonesia pada tahun 2020 menghadapi penyusutan pertumbuhan sebesar 2,07\% dibandingkan tahun 2019 .

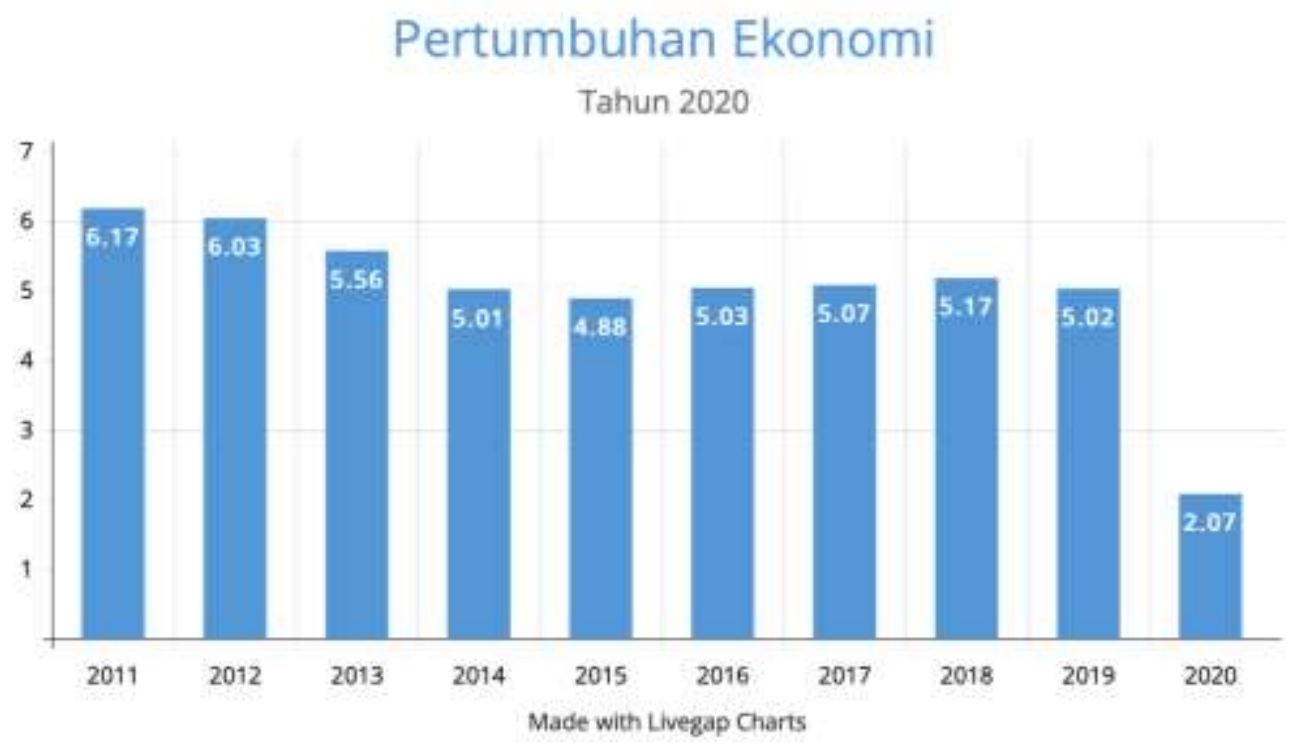

Grafik 1. Pertumbuhan Ekonomi periode Tahun 2020

Sumber: (BPS, 2020)

Pandemi Covid-19 membuat perhatian besar bagi masyarakat Indonesia pada tahun 2020. Akibat pandemi tersebut banyak kerugian yang dialami dan berpengaruh pada perekenomian Indonesia. Meningkatnya insiden Covid-19, pemerintah mulai membuat kebijakan dengan memberlakukan Pembatasan Sosial Berskala Besar (PSBB) untuk mengatasi pandemi Covid-19 yang dilakukan sesuai dengan Keputusan Nomor 21 Tahun 2020. PSBB memaksa melakukan penundaan sementara untuk semua kegiatan yang biasanya berlangsung. Semua aktivitas pada sektor industri serta perkantoran terpaksa untuk dihentikan. Selain itu, sektor pendidikan, pelayanan publik, dan destinasi wisata semuanya juga mengalami hal yang sama. Akibatnya, banyak aspek lain, seperti pekerja sementara dan usaha kecil, terpengaruh. Dimana dari 475 emiten yang melaporkan laporan keuangan mereka pada kuartal I 2020, 4.444 emiten OJK menyampaikan bahwa 58,73\% dari 4.444 emiten mengalami penurunan laba (Utami, 2020).

Pada pertengahan tahun 2020 pemerintah mulai memperbolehkan aktivitas masyarakat seperti semula yang disebut dengan new normal dengan peraturan kesehatan yang telah diatur seperti mengenakan masker, mencuci tangan, dan menjaga jarak antara satu sama lain. Banyak perusahaan yang memperbolehkan karyawannya untuk bekerja seperti semula serta perusahaan mengantisipasi agar karyawannya tidak terkena Covid-19. Perusahaan juga harus berupaya dengan cara menyiapkan fasilitas pendukung seperti tempat mencuci tangan, desinfektan untuk penyemprotan ruangan, penyediaan masker, serta himbauan untuk menjaga jarak. Ketika banyak yang terinfeksi Covid-19 maka akan terganggunya aktivitas di perusahaan serta dapat menyebabkan terhentinya aktivitas perusahaan. Ketika kinerja perusahaan menurun, harga saham di pasar saham juga akan turun. Di sisi 
lain, penurunan jumlah karyawan di sebuah perusahaan menyebabkan peningkatan jumlah pengangguran, yang mempengaruhi kerangka ekonomi secara umum.

\section{Saham IDX BUMN20}

Tahun 2020

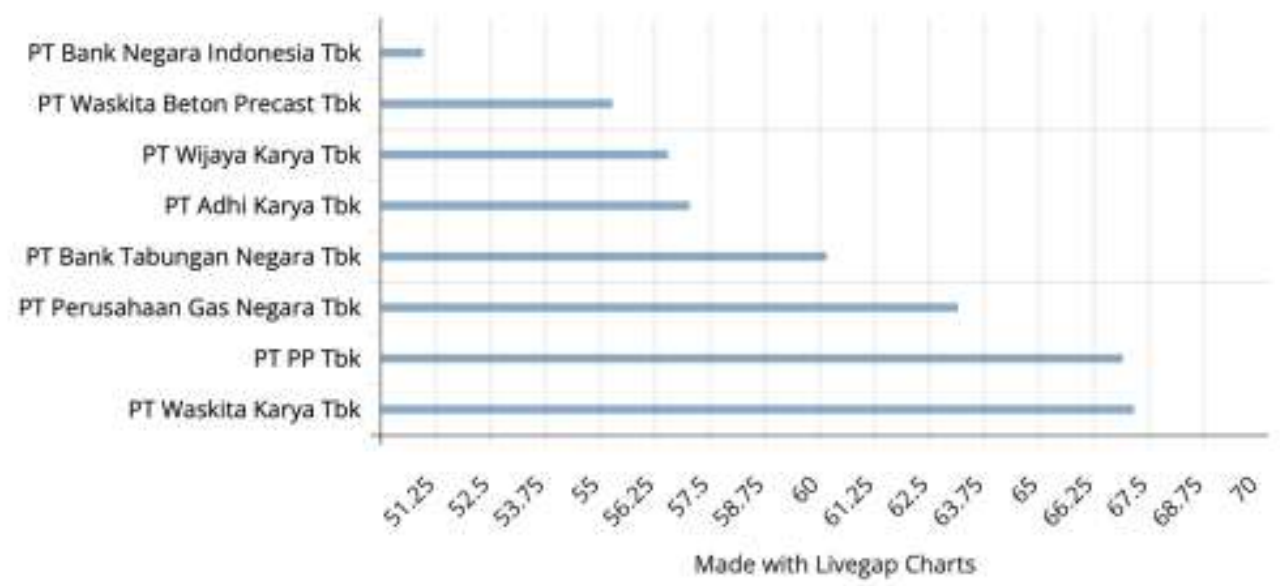

Grafik 2. Indeks Harga Saham IDX BUMN20

Sumber: (IDX, 2020)

Berdasarkan grafik 2 diatas menunjukkan penurunan harga saham IDX BUMN20 di setiap bulannya pada tahun 2019 hingga 2020. Indeks saham IDX BUMN20 juga mengalami penurunan hingga 18,39\% sepanjang tahun 2020. Harga saham ialah harga yang tumbuh sebagai hasil dari suatu pergeseran penawaran dan permintaan yang ada di pasar efek kepada saham yang bersangkutan. Sejak pandemi Covid-19 melanda Indonesia, banyak saham IDX BUMN20 mengalami revisi signifikan. Pandemi Covid-19 berimbas pada perusahaan-perusahaan BUMN. Setidaknya 90 persen kinerja perusahaan negara menurun dan berimbas pada dividen IDX BUMN20 yang diprediksi hanya mencapai 25 persen dari target. Tercatat pada seluruh BUMN yang diamati mempunyai kinerja harga yang kurang baik selama tahun berjalan disebabkan harganya terdepresiasi di tengah pandemi Covid-19. Dari segi fundamental, faktor penurunan indeks IDX BUMN20 disebabkan oleh kondisi terkait pandemi virus Covid-19. Dimana para pelaku pasar sempat optimis bahwa perekonomian akan kembali tumbuh seiring berjalannya waktu. Namun pada kenyataannya pemeritah belum merevisi adanya pertumbuhan yang menjadi lebih rendah. Sementara itu IDX BUMN20 sudah mengalami kenaikan yang signifikan dari koreksi yang terjadi pada awal pandemi. 


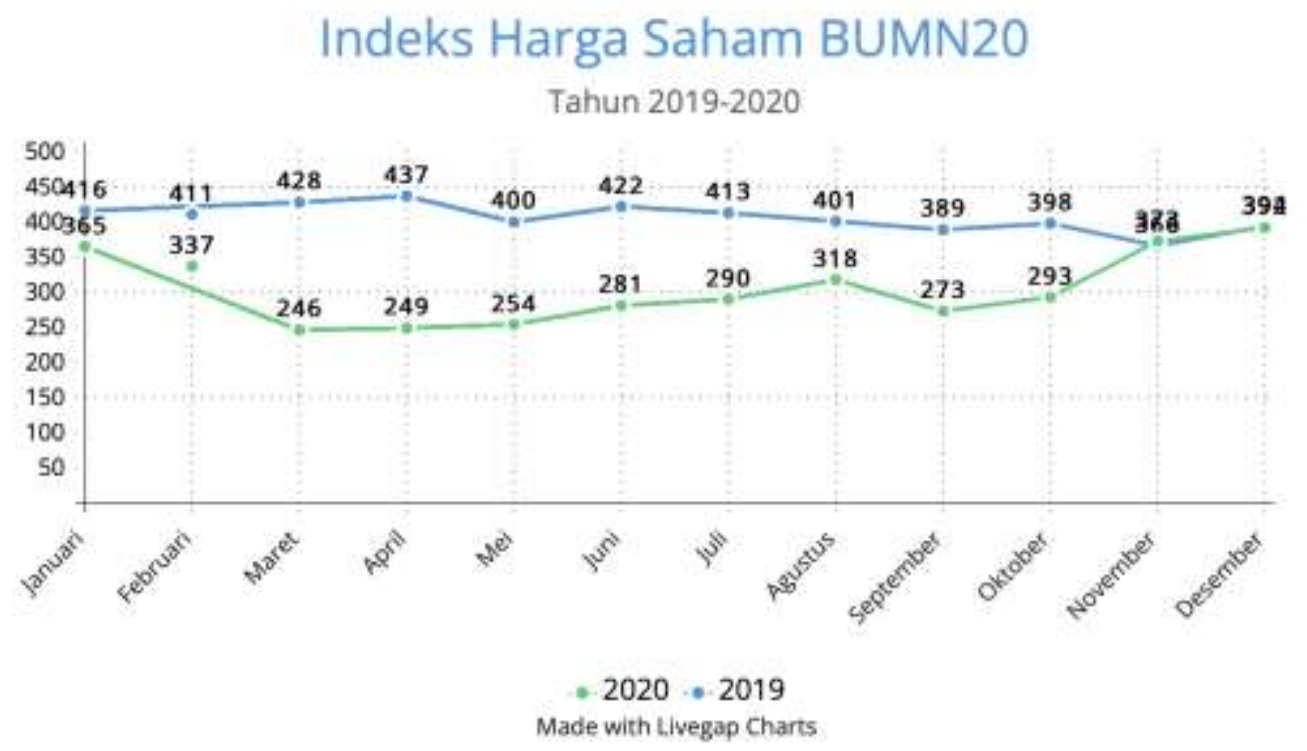

(Sumber: IDX, 2020)

Grafik 3. Saham IDX BUMN20

Grafik diatas menunjukan indeks IDX BUMN20 mengalami penurunan berkisar antara $21 \%$ hingga $67 \%$ ytd. Data diatas menunjukan beberapa saham IDX BUMN20 yang mengalami penurunan harga saham sepanjang tahun 2020. Harga saham umumnya turun ketika pandemi sedang terjadi di Indonesia. Beberapa pemegang saham menjual sahamnya karena bimbang jika harga saham mengalami penurunan yang lebih jauh. Beberapa investor menambah jumlah saham, dengan asumsi harga saham bisa naik sesudah pandemi Covid-19 berakhir. Namun, beberapa investor mengambil resiko dengan memanfaatkan kondisi yang ada dengan membeli lebih banyak saham disaat harga sedang turun. Mereka mengira bahwa kondisi tersebut hanya sementara dan ketika kondisi sudah kembali normal, mereka akan memperoleh keuntungan dan harga saham juga mengalami peningkatan.

Pada umumnya para pemegang saham yang tidak menyukai risiko (afraid to take risk) takut untuk menjual sahamnya karena takut nilai sahamnya mengalami depresiasi dan merugikan. Mereka akan menyimpan jumlah saham dengan keinginan bahwa harga saham akan meningkat saat keadaan sudah kembali normal dan mereka tidak akan menambah atau membeli saham karena khawatir nilainya akan turun. Bagi para investor menengah, biasanya mereka akan menambah jumlah saham, tetapi karena membeli dalam jumlah yang tidak banyak maka kerugiannya tidak terlalu besar meski harga saham turun dan keuntungan keluar saat harga saham naik. Pada akhir tahun 2020 Bursa Efek Indonesia (BEI) mulai membuktikan perbaikan setelah menghadapi tekanan akibat Covid-19. Badan Usaha Milik Negara (BUMN) menunjukkan adanya perbaikan kinerja saham pada kuartal ketiga dimana indeks IDX BUMN20 mengalami kenaikan 36,5\%. Secara umum kinerja saham emiten IDX BUMN20 belum menunjukkan dampak yang cukup besar terhadap kinerja bursa saham, karena tidak semua emiten IDX BUMN20 memiliki kapitalisasi pasar 
yang besar dan hanya beberapa emiten yang mengalami kenaikan. Dengan meningkatnya kondisi makro ekonomi Indonesia dimana kegiatan bisnis sudah kembali berjalan, kinerja IDX BUMN20 juga diharapkan mengalami peningkatan, sehingga dapat mendorong peningkatan pergerakan sahamnya.

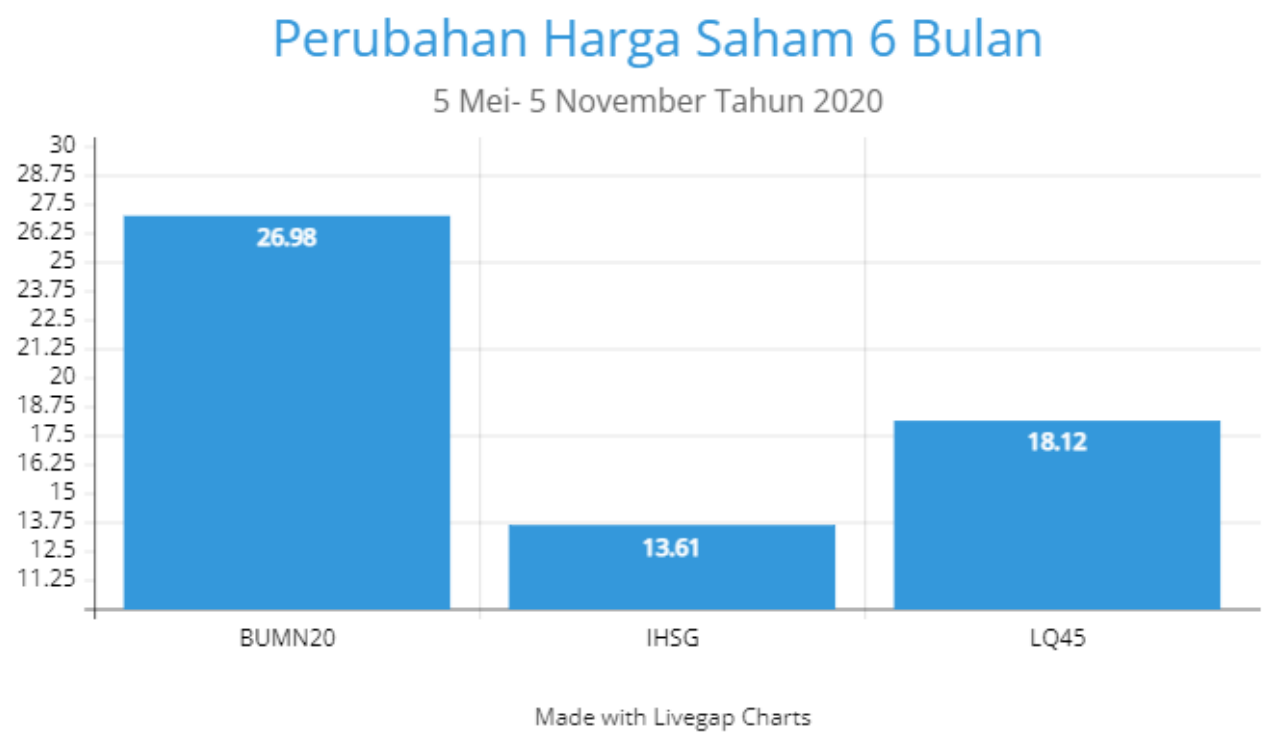

Grafik 4. Perubahan Harga Saham 6 Bulan

(Sumber: Investing, 2020)

Dalam 6 bulan kebelakang, yakni bulan Mei hingga November IDX BUMN20 menujukkan peningkatan indeks harga saham. Tercatat pertumbuhan harga saham yang mencapai $26,98 \%$ pada November 2020. Pertumbuhan harga saham tersebut mengalami kenaikan yang lebih tinggi dibandingkan nilai Indeks Harga Saham Gabungan (IHSG) yang mencapai $13,61 \%$ dan indeks LQ45 yang mencapai $18,12 \%$. Pesatnya pertumbuhan yang dialami indeks IDX BUMN20 terhalang kinerja beberapa emiten BUMN di lintas sektor. Pada tahun 2020 emiten di sektor kesehatan mengalami pertumbuhan tertinggi. Kenaikan ini terdorong karena adanya kejelasan tentang pengembangan vaksin Covid-19. Kimia Farma (KAEF) mengalami penigkatan hingga 136,09\% dibandingkan sebelumnya. Namun, dengan adanya perkembangan kondisi pandemi yang mulai terkendali, vaksinasi yang mulai meluas dan perekonomian yang membaik memberikan potensi untuk meningkatkan kinerja saham yang sudah ada.

\section{PENUTUP}

Berdasarkan hasil yang disampaikan dari ulasan yang sudah dijelaskan pada bagian sebelumnya, maka didapatkan kesimpulan yang pertama yaitu pertumbuhan ekonomi indonesia dari tahun 2019 hingga 2020 mengalami penurunan, dimana pada tahun 2019 pertumbuhan ekonomi sebesar 5.02\% dan pada tahun 2020 sebesar $2.07 \%$, sehingga jumlah penurunan dari tahun 2019 ke tahun 2020 sebesar 2.95\%, hal ini dipicu karena terjadinya pandemi Covid-19 yang mengakibatkan banyaknya 
pekerja yang bekerja dari rumah dan perusahaan yang memberhentikan karyawannya. Yang kedua yaitu indeks saham IDX BUMN20 juga mengalami penurunan hingga 18,39\% sepanjang tahun 2020. Pademi Covid-19 juga memberi tekanan kepada sebagian besar saham Badan Usaha Miliki Negara (BUMN). Namun pada akhir tahun 2020 indeks saham IDX BUMN20 mengalami pertumbuhan nilai saham yang lebih besar dari pada Indeks Harga Saham Gabungan (IHSG) dan LQ45 pada 6 bulan terakhir. Selain itu beberapa emiten BUMN juga mengalami pertumbuhan terutama emiten pada sektor kesehatan yang mengalami kenaikan hingga $136,09 \%$.

Dari hasil pembahasan yang telah diuraikan, saran yang dapat dibagikan dari penulis, yakni pertama bagi para investor atau pemegang saham bahwa sebelum mempunyai keinginan untuk melakukan investasi harus lebih memperhatikan dan melihat berbagai faktor yang dapat mempengaruhi harga saham kedepannya, terutama dalam masa pandemi Covid-19, dimana harga saham yang mungkin mengalami penurunan dan pertumbuhan yang cukup drastis. Lalu untuk peneliti selanjutnya diharapkan untuk dapat menambah contoh penelitian supaya penelitian yang dilakukan menjadi lebih lengkap dan menyeluruh. Selain itu peneliti diharapkan untuk dapat memperhatikan lagi kejadian atau variabel lainnya seperti yang dapat mempengaruhi pasar saham IDX BUMN20 di Indonesia.

\section{DAFTAR PUSTAKA}

Bappenas RI. (2020). Perkembangan Ekonomi Indonesia dan Dunia: Ancaman

Resesi Dunia Akibat Pandemi. Jakarta: Kementerian PPN/BAPPENAS.

Bursa Efek Indonesia. (2021). SEJARAH \& MILESTONE. Diambil dari : https://idx.co.id/tentang-bei/sejarah-dan-milestone/

CCN Indonesia, (2020). Corona Tembus 30 Ribu, Urutan ke-2 di Asean. Diakses dari : $\quad$ https://www.cnnindonesia.com/nasional/20200606124855-20510461/corona-tembus-30-ribu-indonesia-urutan-ke-2-di-asean

CCN Indonesia, (2021). Jejak Pandemi Covid-19, dari Pasar hingga Mengepung Dunia.

Diakses dari https://www.cnnindonesia.com/internasional/20210804100935-113676183/jejak-pandemi-covid-19-dari-pasar-hingga-mengepung-dunia

Covid-19, G. T. P. P. (2020) Perkembangan Kasus Terkonfirmasi Positif Covid-19. Diakses dari : https://covid19.go.id/peta-sebaran

Jayani, D.H. (2020). Sejumlah Kunci Pendongkrak Kinerja Saham BUMN di Bursa. Diakses dari https://katadata.co.id/muhammadridhoi/analisisdata/5fb337b33f6eb/sejumlahkunci-pendongkrak-kinerja-saham-bumn-di-bursa

Laoli, Noverius. (2020). Indeks BUMN20 anjlok 38,25\% sejak awal tahun, ini 10 saham penurunan terdalam. Diakses dari : https://investasi.kontan.co.id/news/indeks-idx-bumn20-anjlok-3825-sejak-awaltahun-ini-10-saham-penurunan-terdalam

Nasution, D. A. D, Erlina, Iskandar Muda. (2020). DAMPAK PANDEMI COVID -19 TERHADAP PEREKONOMIAN INDONESIA. 
Nurhaliza, Shifa. (2021). Cara Kerja Pasar Saham Perlu Dipahami Investor. Diakses dari : https://www.idxchannel.com/market-news/cara-kerja-pasar-saham-perludipahami-investor-simak-penjelasannya

Peraturan Pemerintah. Nomor 21 Tahun 2020 Pembatasan Sosial Berskala Besar Dalam Rangka Percepatan Penanganan Corona Virus Disease 2019 (Covid19).

Putra, Tri. (2020). Semester 1- 2020, Semua Saham BUMN Merah \& Ada yang Drop 52\%. Diakses dari : https://www.cnbcindonesia.com/market/2020070115481217-169483/semester-i-2020-semua-saham-bumn-merah-ada-yang-drop-52

Saraswati, Henny. (2020). Dampak Pandemi Covid-19 Terhadap Pasar Saham Di Indonesia.

Studioekonomi.com. (2020). Pertumbuhan Ekonomi 2020 Minus, lebih rendah dari perkiraan pemerintah.

Diakses

dari

https://studiekonomi.com/nasional/pertumbuhan-ekonomi-2020-minus-lebihrendah-dari-perkiraan-pemerintah/

Utami, D. N. (2020) Laporan OJK: Kuartal I/2020, 58 Persen Emiten Alami Penurunan Laba, market.bisnis.com. Diakses dari

https://market.bisnis.com/read/20200722/192/1269735/laporan-ojk-kuartali2020-58-persen-emiten-alami-penurunan-laba 